\title{
CONSERVATION-BASED BREEDING PROGRAM FOR INDIGENOUS SHEEP BREEDS IN ETHIOPIA: THE WAY FORWARD
}

\author{
Meseret MOLLA \\ University of Gondar, College of Veterinary Medicine and Animal Sciences P.O.Box 196, Ethiopia \\ Email: meseretmo@yahoo.com; (1) ORCiD: 0000-0002-8028-110X \\ Supporting Information
}

\begin{abstract}
This paper review briefly Ethiopian sheep genetic resources, description of farming systems, breeding objectives of the community, and to quantify threats with previous sheep genetic improvement and conservation strategies in Ethiopia. Thus, the aims of this paper focus on the role of characterizing indigenous sheep breed, including their threat status in genetic improvement programs. Indigenous sheep genetic resources have contributed considerable portion to the integrated crop-livestock farming systems in Ethiopia. Ethiopia endowed with a diverse sheep genetic resource maintained under different production systems. Sheep research and development in Ethiopia has largely focused on characterization of sheep genetic resources, description of farming systems and genetic improvements using crossbreeding and selection within breed. In Ethiopia, there are a total of 14 traditional sheep populations in Ethiopia fall into six breed groups based on DNA and morphological data. The main cause of threatening the sheep genetic resource in Ethiopia is indiscriminate crossbreeding with exotic germplasm. Few research institutes and agricultural universities are involved in the conservation and management of sheep breeds in Ethiopia. Currently the emphasis is on village based rather than centre-based genetic improvement program. It is possible to conserve sheep genetic resources in Ethiopia through quantifying past sheep characterization works and developing breeding programs suitable to the conditions of smallholder farmers that increase the economic values of indigenous sheep breeds.
\end{abstract}

Keywords: Conservation, Indigenous, Sheep, Smallholder farmer, Village breeding practice

\section{INTRODUCTION}

The issue of loss of diversity and conservation of farm animal genetic resources has gained momentum in the last few decades. Correspondingly, there have been tremendous efforts globally to study genetic diversity in livestock species addressing the needs of both development and conservation of animal genetic resources in the different parts of the world. Livestock are essential components of Ethiopian agriculture and the country is reported to have the largest livestock resource than any other African country. Ethiopia is recognized to possess one of the most diversified livestock populations in Africa. The population of small ruminants owned by the country is estimated to be 56.6 million heads of small ruminants (CSA, 2015). Of this number, the sheep population accounts for about 28 million heads. This livestock sector has been contributing considerable portion to the economy of the country, and still promising to play significant role in the economic development of the country. It is eminent that sheep products in the form of meat could play a pivotal role as a good source of animal protein since they have short generation interval and affordable by resource poor farmers (Markos, 2006; Tsegaye et al., 2013).

The sheep in the country is produced under an extensive low input subsistence system. Similar to other tropical countries, studies noted that productivity of indigenous sheep in terms of meat has been limited by poor genetic potential (Markos, 2006; ILRI, 201; Getahun, 2008). Among the various factors, absence of planned genetic improvement programs for local breeds is one of the causes for losing their competitive advantage, especially where production systems or external conditions are subject to change (Hiemstra et al., 2007).

Moreover, lack of adequate information on indigenous livestock genetic resources has been recognized to be a serious constraint to effective prioritization and planning of sustainable breeding strategies and breed conservation measures. As a result, a number of activities aimed at the characterization of the major livestock genetic resources have been carried out by different governmental and non-governmental organizations (IBC, 2004).

This review paper provides an overview of the current state of knowledge on characterization of sheep genetic resources, production system, existing breed management, traditional breeding practice and identification of important traits of indigenous sheep breeds in Ethiopia. Finally, gaps in current knowledge are identified, and priorities for future research are proposed. 


\section{LITERATURE REVIEW}

\section{Sheep genetic resources of Ethiopia}

Ethiopia is one of the countries in the world, which has contributed richly to the global livestock gene pool. Estimates indicated that about $99.9 \%$ of the total sheep population in Ethiopia is indigenous breeds (CSA, 2015). According to (Solomon et al., 2007b; Solomon et al., 2008a), Ethiopian sheep are classified into 15 traditional sheep populations, which fall into four breed groups and nine breeds based on diversity analysis using microsatellite markers and morphological diversity.

Exotic breeds represent a very insignificant proportion of the national flock and some of the exotic sheep breeds that have been introduced into the country include: Dorper, Merino, Romney, Corriedale, Hampshire, Awassi, and Blue de Main. Only very few of these or their crosses are seen either in rural or urban areas. Some were limited to research stations while others have been and are still being distributed to farmers (Sisay, 2009; Solomon and Tesfaye, 2009). Sisay (2009) phenotypic ally characterized local sheep population of Amhara National Regional State of Ethiopia into five distinct major groups.

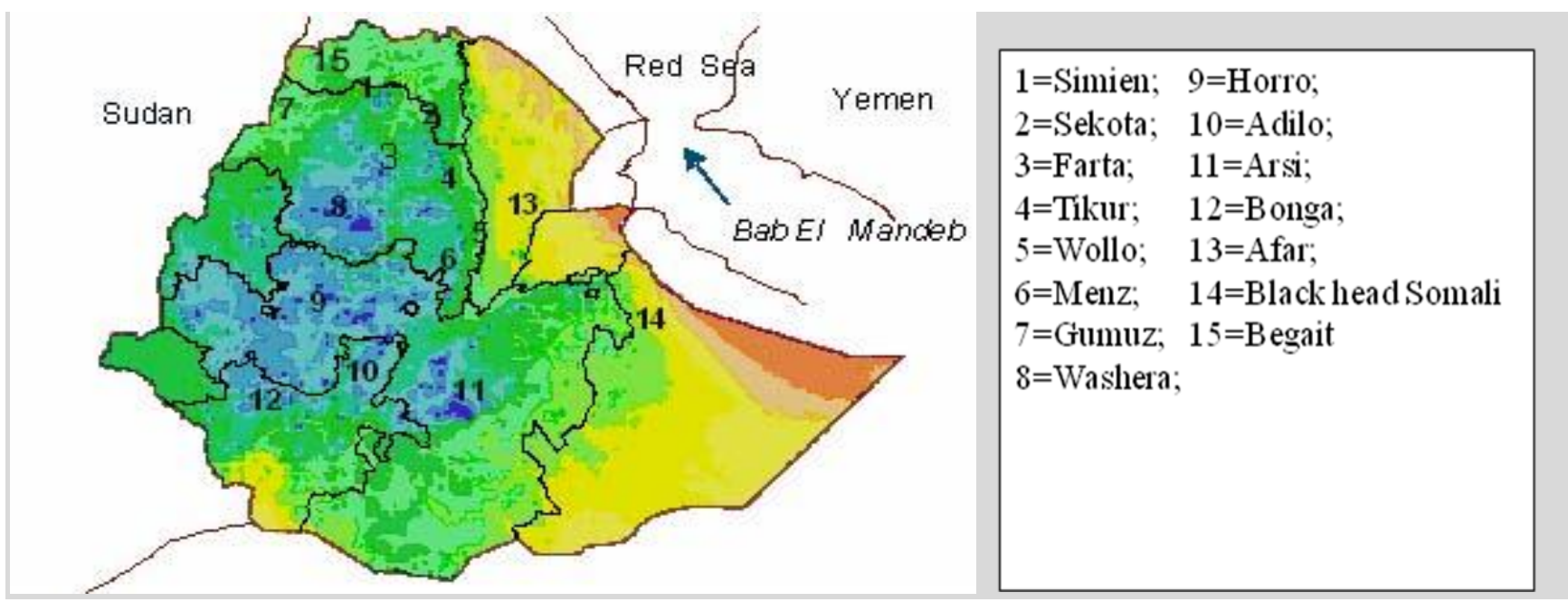

Figure 1 - Geographic distribution of Ethiopian sheep breeds (Solomon, 2008)

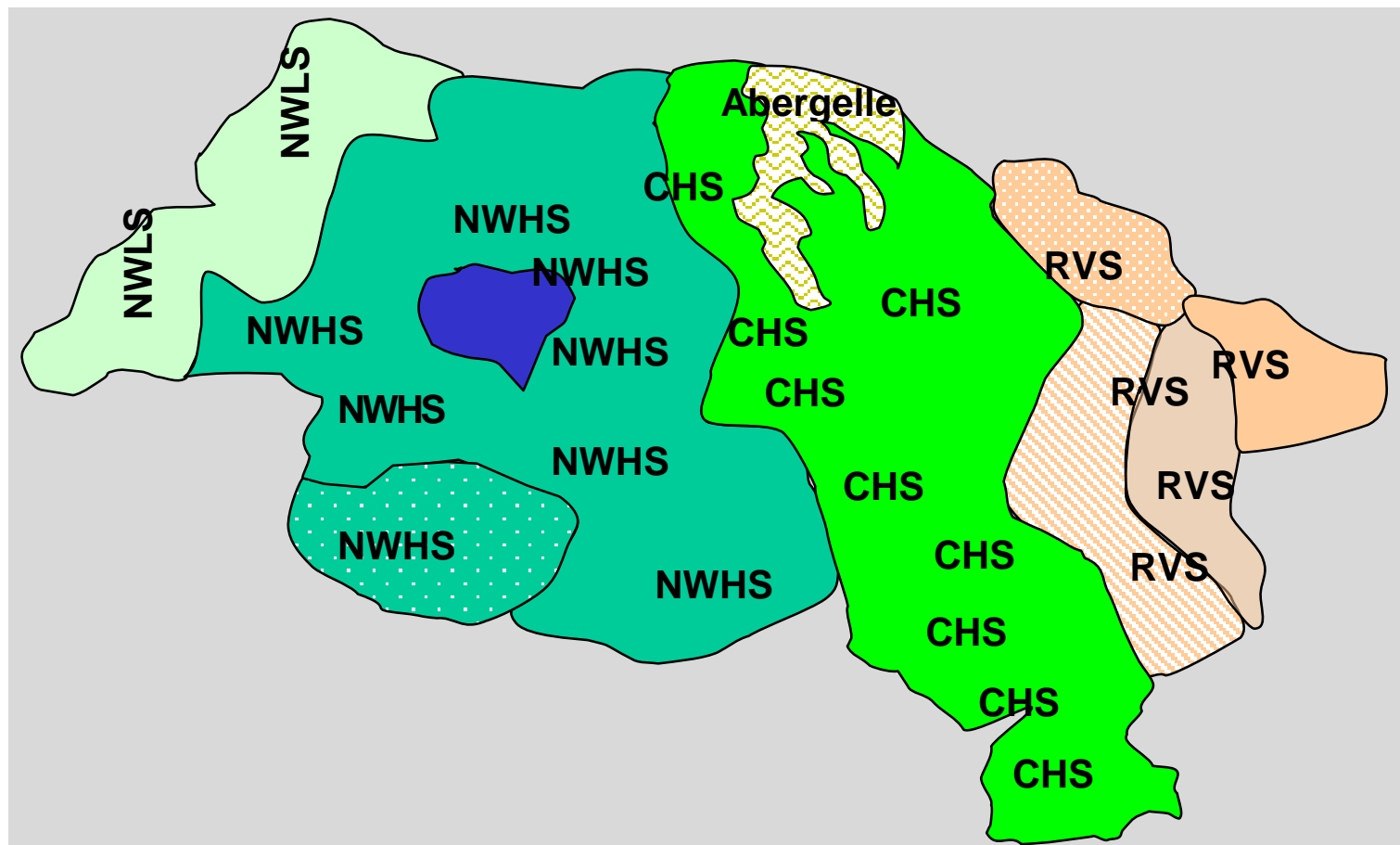

Figure 2 - Agro-ecological distribution of the five major sheep types in the Amhara region. CHS: Central Highland sheep; NWHS: North-western Highland sheep; RVS: Rift Valley (Afar) sheep ; Abergelle: Abergelle sheep; NWLS: North-western Lowland (Gumez) sheep. 
This diversity is relevant in terms of specific adaptation to the various agro-ecological zones where the breeds exist, for instance attributes like heat tolerance, disease resistance and drought tolerance. These characters help the breeds to survive and produce under prevailing environmental challenges of the different agro-ecological zones of the country. Despite presence of sizeable amount of information to describe the sheep types in Ethiopia, there is still gap to be filled in terms of comprehensive characterization of the sheep population at district level as an input to prioritize for conservation and development of breeding program towards sustainable utilization (Solomon et al., 2011d; Solomon et al., 2013; Tesfaye et al., 2016). The gaps which require comprehensive characterization like in specific areas which have production system and production environment change in areas in which the current climate change affect the adaptation of certain breeds which initiate the community to cross with other adaptable breed in the neighboring areas. This will be used as an input to prioritize for conservation and development of breeding program towards sustainable utilization. The importance of genetic diversity has not been given adequate attention for the sustainable utilization of various breed by different stakeholders including the community in the past and even at present. There is limited location specific information on components of characterization including description of the production system and environment, performance levels of the breeds, and farmers breeding practices and objectives and the threat status of indigenous sheep population in the country (Solomonet al., 2011d).

The loss of genetic variation within and between breeds is detrimental not only from the perspectives of adaptability but also for utility since lost genes may be of future economic interest. The reasons for loss of genetic diversity within and between breed are many, including the low productivity of the local breeds, neglect the potential of good indigenous breeds, lack of well-defined breeding objectives, inappropriate development policies and management strategies, disease outbreaks, various types of disasters and emergencies (FAO, 2007b). Therefore, research and development on conservation of sheep genetic resources in developing countries and particularly in Ethiopia is the most crucial and urgently needed (Solomon et al., 2013). Thus, location specific characterization on the production system, farmers breeding practices, identification of breeding objective traits in participatory manner and performance evaluation of the breeds should be conducted. There is also a need to verify the threat status of endangered livestock breeds and take measures to conserve them. The information generated might be required to design sustainable conservation-based utilization programs.

\section{Characterization of Sheep Production Systems}

Sheep production systems in Ethiopia are predominantly traditional (Markos, 2006; Solomon et al., 2010b). According to the degree of integration with crop production, level of input, agro-ecology, relation to land and type of commodity to be produced and mobility, the traditional sheep production system can be sub divided into five systems (Solomon et al., 2008a). These are subalpine sheep-cereal system, highland cereal-livestock system, highland perennial crop system, lowland crop-livestock system or agro-pastoral system and pastoral production system. A brief account of these systems as indicated in the literatures is discussed below.

\section{A) The subalpine sheep-cereal system}

This system is found in the highland areas (above 3000 m.a.s.l.) of Ethiopia where the major crops grown are barley and pulses such as faba beans and lentils. Sheep are the dominant livestock species and reared mainly for source of income, meat, manure, skin and coarse wool (Tesfaye et al., 2010; Shigdaf et al., 2013; Mesfin et al., 2014b). In the subalpine system, numbers of sheep in a flock are larger, typically comprising 10-30 animals (Markos, 2006; Solomon et al., 2010b; Tesfaye et al., 2010). The maintenance of pure-bred Menz sheep flocks at Debre Berhan Research Centre and community based breeding programs at Debre Berhan and Menz area are the conservation attempts made in this production systems (Solomon et al., 2013).

\section{B) Highland cereal-livestock system}

The system covers an area with an altitude between 2000 to 3000 m.a.s.l. and characterized by adequate rainfall and moderate temperature which is suitable for cereal production. In this system, sheep production is found in association with the different agricultural production systems which vary in potentials, intensity of the mixed farming operation and natural resources including grazing and livestock resources (Samuel, 2005). According to Dereje and Tesfaye (2008), sheep are kept in small flocks and provide cash income, meat, manure and skins. On-station improvement of Horro sheep at Bako Agricultural research center is primarily used as the active breeding of Horro sheep populations (Duguma et al., 2010). In addition, in situ conservation of Horro sheep through community based breeding programa at Bako and Shambu area is also use as part of an ongoing livelihood and conservation strategy in the production system (Tadele et al., 2012).

\section{C) Highland perennial crop system}

This system is common in the Highlands with an altitude range of 1500 to 2000 m.a.s.l. In this farming system, livestock holdings are small, the topography is uneven and inter-cropping is practiced (Zewdu et al., 2012). Under this system livestock production is of minor importance and is characterized by cultivation of a combination of cash and subsistence crops such as inset and fruit, chat, coffee and tea (Belete, 2009). The integration of crop-livestock mixed 
farming is lower in the perennial system. Sheep are kept by smallholders, graze and rear together with goat and/or other livestock species such as cattle (Zewdu et al., 2012).

\section{D) Lowland crop-livestock system or agro-pastoral system:}

This system found in the sub-moist/moist lowland areas ( $\leq 1000$ m.a.s.l.) with higher rainfall to support short season crops (cereals, sesame and cotton) compared to the pastoral system and it is characterized by less integration with crop production (Tesfaye et al., 2010). This production system is associated with the purely livestock based nomadic and transhumance pastoral production systems dependent largely on range, primarily using natural vegetation. In the lowlands of Ethiopia, livestock is comprised of large flocks and herds of sheep, goats, cattle and camels and it is mainly transhumant. Extensive livestock keeping is the backbone of the economies of this system (Fekerte, 2008).

\section{E) Pastoral production system:}

This system is located in the arid and semi-arid lowland areas ( $\leq 1000 \mathrm{~m}$.a.s.l.) where livestock rearing is the mainstay of people (Markos, 2006). It is characterized by high mobility in search of grazing and water. In this system, extensive livestock production is mostly the sole source of livelihood with little or no cropping (Solomon et al., 2010b). Livestock, including small ruminant production is associated with the purely livestock based nomadic and transhumance pastoral production systems based largely on range, primarily using natural vegetation. The variability of rainfall is the greatest threat to crop production. Sheep are kept by nearly all pastoralists, often in mixed flocks with goat (Solomonet al., 2008a; Tesfayeet al., 2010).

\section{Definition of Breeding Objectives}

Defining breeding objectives involves identifying breeding-objective traits, deriving their relative importance, and constructing the aggregate genotype that can subsequently be translated into a selection index (Solomon et al., 2008a and Kosgey et al., 2008). Definition of breeding objectives traits is the basis for designing appropriate animals breeding programs (Sölkner et al., 1998; Gemeda et al., 2010 and Wurzinger et al., 2011). In smallholder and pastoral communities, breeding goals are multi-functional incorporating both tangible and intangible benefits of sheep keeping. Therefore, when defining animal breeding objectives in low input systems, the needs and interests of the target group should be incorporate to increase the success of breed improvement programs (Kosgey et al., 2008 and Tesfaye et al., 2010). Lack of participation of farmers in defining the breeding objective was the main reason for failure of many livestock improvement programs in the tropics (Wurzinger et al., 2011).

Participatory approaches of defining breeding objectives have been described by a number of studies (Kahsa, 2009; Solomon et al., 2010b; Tesfaye et al., 2010; Zewdu et al., 2012). Such approaches have been used for mixed croplivestock and pastoral systems for definition of breeding objectives in goats and in sheep (Grume et al., 2013 and Tadelle et al., 2012). Participatory approaches have also been used in determining objectives of keeping dairy goats and for studies of farming systems for small ruminants in Kenya (Kosgey et al., 2008). Gemeda et al. (2010) recommended five alternative approaches (direct ranking, workshops, choice cards, own and group flock ranking) to identify the breeding objectives and the breeding objective traits in pastoral and smallholder subsistence system. Direct ranking using structured interviews with the sheep owners have often been used when identifying traits of importance for a breeding program (Ilatsia, 2011).

After listing of preferred traits, there should be a score assigning for each of the traits or trait categories. Ranking of animals from own flock implies grading of own animals based on reproduction and production performances. The sheep owners are asked to rank their own animals (female and males) from the 1st (best), 2nd (second best) and 3rd (poorest), and should indicate reasons for their ranking (Sölkner et al., 1998; Gemeda et al., 2010). After receiving detailed information from the owners, body weight and other linear body measurements are taken on each individual ranked animal. Gemeda et al. (2010) also suggested that a combination of methods can be used to extract breeding objectives of the community. The information obtained through these methods can be used to design village-based selection breeding programs.

The diverse traits (body size, color, milk yield, lamb survival, twinning, walk ability, lambing interval and longevity) as the selection criteria during direct-ranking for breeding animals are well documented in many research reports (Grume et al., 2013; Tesfaye et al., 2010; Zewduet al., 2012; Gemeda et al., 2010; Tadelle et al., 2012). According to Grume et al. (2013) and Tadelle et al. (2012) and Solomon (2014), productive and reproductive traits were frequently mentioned during the own flock-rankings for breeding animals. Moreover, Zewdu (2008) also argued in favor of including reproductive traits not only based on economics of production, but also because of its influence in genetic improvement through selection intensity. Gemeda et al. (2010), Kahsa (2009) and Zander et al. (2009) reported that choice experiments are important for identifying selection criteria in subsistence production systems and evaluated cattle and sheep trait preferences of pastoralists and smallholder farmers in Ethiopia. Previous breeding objective traits identification studies (Tadelle et al., 2012 and Berhanuet al., 2012) indicated that body size, body conformation, twinning, color and beauty related traits were considered as important traits of preference for breeding animals during group animal ranking experiments. 


\section{Genetic Improvement and Conservation Strategies}

Livestock productivity can be increased through genetic improvement. Strategies for genetic improvement of livestock mainly involve the decision on the use of genetic variation within a breed (selective breeding) or between breeds (crossbreeding) (FAO, 2007b; Philipsson, 2000). The sheep breeding strategies adopted in Ethiopia over the last several decades largely focused on importing exotic breeds for cross-breeding (Markos, 2006; Solomon et al., 2013; Tesfaye et al., 2016). However, study of Solomon et al. (2013) and Tesfaye et al. (2010) indicated that the impact of decades of this program is negligible.

This has been due to poor involvement of stakeholders and implementing livestock improvement programs without taking into consideration the needs of farmers (Markos, 2006; Gemeda et al., 2010 and Tadelle et al., 2012). The distribution of the improved genotypes of these programs was indiscriminate and unplanned, resulting in failure of the breeding programs and threatened to dilute the sheep genetic diversity in the country (Solomon et al., 2011d). There are also well documented examples of unsuccessful projects using exotic breeds (Taberlet et al., 2011) in developing countries. Therefore, appropriate conservation-based breeding strategies are needed to avoid indiscriminate crossbreeding as well as to improve sheep production and productivity of the locally adapted breeds like Gumz sheep. Philipsson (2000) suggested that in order to increase livestock productivity in developing countries like Ethiopia, diversity within indigenous breeds should be efficiently exploited. Open nucleus schemes and community/village-breeding programs are being increasingly advocated for traditional production systems (Zewdu, 2008). Although the indigenous livestock genetic resources of Ethiopia have high within breed genetic variations (Solomon et al., 2008a) and desirable characteristics, there has been little effort to improve the genetic merits of the local livestock genetic resources using the within breed genetic variation. However, in Ethiopia, like in the other parts of the developing countries small flock sizes, lack of animal identification, lack of performance and pedigree recording, low level of literacy and organizational shortcomings and flock mobility have been major constraints that hinders within breed selection (Markos, 2006; Solomon and Tesfaye, 2009). To overcome these problems, nucleus breeding schemes have been suggested as tools for small ruminant genetic improvement programs in tropical countries (Markos, 2006; Mueller, 2006). The scheme could be utilized for conservation of genetic resources through improvement and proper utilization. This scheme can serve for both pure-breeding and crossbreeding, and dissemination of improved genetic materials allowing conservation and improvement of the indigenous sheep breeds. However, implementation of nucleus breeding schemes in low-input environments has proven to be difficult because of requirement of long term commitment of sponsors and involvement of farmers (Solomon and Tesfaye, 2009; Kosgey et al., 2008). Village based breeding schemes have also been suggested as an alternative to nucleus scheme. Recently, community based breeding strategy has been gained momentum for increasing productivity of indigenous sheep of Ethiopia (Solomon et al., 2013; Gemeda et al., 2010; Tadelle et al., 2012), as a means to improve the livelihood of smallholder farmers as well as to conserve the existing genetic diversity through utilization. Community (village)-based breeding schemes is also a recently suggested viable option for the genetic improvement programs of small ruminants in low-input, smallholder production systems in the tropics (Kosgey et al., 2008; Wurzinger et al., 2011).

\section{A) Central Nucleus Breeding Schemes}

Sheep production in developing regions is generally characterized by small flock size, uncontrolled mating, and the absence of pedigree and performance recording (Markos, 2006; Solomon and Tesfaye, 2009). These characteristics limited the implementation of effective genetic improvement programs. To overcome these problems, nucleus breeding schemes have been suggested for tropical countries, in which genetic improvement is centrally organized in a population maintained in research institutes or government farms. The open nucleus breeding scheme offers a simple procedure for producing and disseminating breeding stock of high breeding value. Based on breeding values for the breeding goal traits, ewes born to superior rams would be selected and bought for transfer to nucleus flock. Nucleus flocks will be set-up in the governmental breeding ranches. Subsequent genetic evaluations and selection for superior rams would be undertaken in the nucleus flocks where animals from different sources are evaluated in the same environment. Dissemination of superior rams to participating farmers will be made on cost recovery basis. Several studies indicated the significance of using open nucleus breeding scheme to increase the rate of genetic gain (Philipsson, 2000; Yapi-Gnoare, 2001). Markos (2006), has also been presented a plan for the indigenous Horro sheep open-nucleus breeding scheme in Ethiopia. This scheme could be utilized for conservation of genetic resources (including breeds, desirable genes, genotypes, etc) through improvement and proper utilization (Markos, 2006; Philipsson, 2000). This scheme can serve for both pure-breeding and crossbreeding and dissemination of improved genetic materials allowing conservation and improvement of the indigenous sheep breeds. On-station breed evaluation work of some well-known sheep types has been undertaken. These include the Ethiopian Agricultural Research Institutes (EARI) evaluation program on Afar, Black Head Somali (BHS), Menz and Horro sheep. Major emphasis in all of these studies was on meat production and wool (Menz sheep) production. Results in a nucleus flock of Menz sheep indicated that genetic progress of $0.29 \mathrm{~kg}$ and $0.34 \mathrm{~kg}$ (Solomon et al., 2014a) in a six month weight was achieved. Selection in the Horro sheep nucleus flock did not result in appreciable genetic improvement and the breeding program shows no progress (Solomon and Duguma, 2000; Solomon et al., 2007a). Whereas results of selection in the nucleus flocks of Afar and BHS sheep remain unreported. 


\section{B) Village based Breeding Schemes}

A community-based breeding program refers to village-based breeding activities planned, designed, and implemented by smallholder farmers, individually or cooperatively, to effect genetic improvement in their flocks and conserve indigenous genetic resources (Sölkner et al., 1998). The design of these programs considers description of the production system, definition of the breeding objective traits of the farmer and assessment of alternative schemes (Mueller, 2006; Baker and Gray, 2004; Sölkner-Rollefson, 2003; Aynalem et al., 2008). Solomon et al. (2011c,d) showed that this new community-based or village centered approach in animal breeding can be used for smallholder system as this ensures the full participation of the farmers and is more sustainable in the long term as it is less dependent from external inputs. This program is also intended to overcome the problems of genotype-environment interaction, avoid the genetic lag between nucleus and village populations, and are appropriate for in situ conservation of indigenous animal genetic resources (Solomon et al., 2011d). Village based breeding scheme had been tried in a number of areas (for example, on Menz sheep in DebreBerhan and MehalMeda area, Horro sheep in Shambu areas, Afar sheep in Afar area and Bonga sheep in Bonga area) and has been found successful in improving the growth performance of the sheep (Gemeda et al., 2010; Tadelle et al., 2012). For instance, body weights of Menz sheep at birth, 3 and 6 months of age increased by $0.42,2.29$ and $2.46 \mathrm{~kg}$, respectively, in the third generation over the base generations. However, genetic progresses in lamb survival and litter size were low on the local Menz sheep breeds (Tadelle et al., 2012).

\section{CONCLUSION}

It is clear that information in production systems, breeding objective traits and improvement breeding programs from numerous research projects have been reviewed. Currently available information could help decision-makers formulate in better way sustainable development programs for conservation and utilization of sheep genetic resources. While inventory of species and breeds, their population sizes and geographic distribution for the management of animal genetic resources remains poor. There are also gaps in research and development efforts. Thus, the next step should focus on designing of breeding strategies suitable for smallholder production system for sustainable management of diversity among promising and widely used local breeds.

\section{DECLARATIONS}

\section{Corresponding author}

Meseret Molla; Email: meseretmo@yahoo.com

\section{Acknowledgement}

I would like to express my great acknowledgement to Dr. Yohannes Dagnew for his support in sharing the materials to write this review article.

Authors' contribution

I fully engaged in the reviewing processes of this paper.

\section{REFERENCES}

Aynalem H, Markos T, Gemeda D, Tadelle M, Wurzinger M and Sölkner J (2008). Community-based sheep breeding: a new approach to genetic improvement. pp.231-241. Procceding of the 16th Annual Conference of the Ethiopian Society of Animal Production (ESAP), 8-10 October 2008, Addis Ababa, Ethiopia.

Baker RL and Gray GD (2004): Appropriate breeds and breeding schemes for sheep and goats in the tropics. In: Sani, R.A., Gray, G.D., Baker, R.L. (eds.), Worm Control for Small Ruminants in Tropical Asia, Canberra, ACIAR Monograph, 113: $63-96$.

Belete S(2009): Production and marketing systems of small ruminants in Goma district of Jimma zone, western Ethiopia. MSc thesis, Hawassa University, Hawassa, Ethiopia.

Berhanu T, Thiengtham J, Tudsri S, Abebe G, Tera A and Prasanpanich S (2012): Purposes of keeping goats, breed preferences and selection criteria in pastoral and agropastoral districts of South Omo Zone. Livestock Research for Rural Development 24 (12) 2012.

CSA (2015). Report on livestock and livestock characteristics (private peasant holdings). Central Statistical Agency (CSA): Addis Ababa, Ethiopia.

Dereje T and Tesfaye L (2008): Livestock production systems in Darolebu, Habro and Boke districts of western Harereghe.pp. 179-186. Proceedings of the $16^{\text {th }}$ conference of the Ethiopian Society of Animal Production (ESAP), 8-10 October 2008, Addis Ababa, Ethiopia.

FAO (2005). Production yearbook. FAO, Rome, Italy.

FAO (2007b). The state of the world's animal genetic resources for food and agriculture, B Rischkowsky and D Pilling, Food and Agriculture Organization of the United Nations, Rome, 511

Fekerte F (2008): On-farm Characterization of Blackhead Somali Sheep Breed and Its Production System in Shinile and Erer Districts of Shinile Zone. MSc Thesis, Haramaya University, Haramaya, Ethiopia.

Gemeda D, Tadelle M, Aynalem H, Iñiguez L, Okeyo AM, Markos T, Rischkowsky B, Sölkner J and Wurzinger M (2010): Participatory approaches to investigate breeding objectives of livestock keepers. Livestock Research for Rural Development, 22(64)

Getahun L (2008): Productive and Economic performance of Small Ruminant production in production system of the Highlands of Ethiopia. PhD. Dissertation, University of Hohenheim, Stuttgart-Hoheinheim, Germany. 
Grume G, Aynalem H and Tadelle D (2013): Breeding scheme based on communitybased participatory analysis of local breeding practices, objectives and constraints for goats around Dire Dawa, Ethiopian. Livestock Research for Rural Development, 25 (3).

Hiemstra SJ, Drucker AG, Tvedt MW, Louwaars N, Oldenbroek JK, Kassahu K, Solomon A, Bhat PN and da Mariante Silva A (2007): Options for strengthening the policy and regulatory framework for the exchange, use and conservationofanimal genetic resources.Animal Genetic Resources Information, 41:65-74.

IBC (2004). The State of Ethiopia's Farm Animal Genetic Resources: Country Report. A Contribution to the First Report on the State of the World's Animal Genetic Resources. IBC, May 2004. Addis Ababa, Ethiopia.

Ilatsia ED (2011): Breeding Strategies for Sahiwal Cattle Genetic Resources in Kenya. Doctoral Dissertation, Hohenheim University, Germany.

ILRI (2011). Livestock policy analysis. ILRI Training Manual 2. ILRI, Nairobi, Kenya.

Kahsa T (2009): Estimates of economic values for important traits of two indigenous sheep breeds of Ethiopia. MSc thesis, Boku, Vienna, Austria.

Kosgey IS, Rowlands GJ, van Arendonk JAM and Baker RL (2008): Small ruminant production in smallholder and pastoral/extensive farming systems in Kenya. Small Ruminant Research, 7:11-24.

Markos T (2006): Productivity and health of indigenous sheep breeds and crossbreds in the central Ethiopian highlands.Doctoral Thesis, Swedish University of Agricultural Sciences. Uppsala, Sweden

Mesfin L, Mussie H and Getinet M (2014b): Evaluation of Growth Performance of Local and Dorper x Local Crossbred Sheep in Eastern Amhara Region, Ethiopia, Iranian Journal of Applied Animal Science, 4, 123-126.

Mueller JP (2006): Breeding and conservation programs with local communities. FAO WAAP workshop "Sustainable utilization as a support to the further development of the global strategy for animal genetic resources management”, Ferentillo, Italia, June 28 - July 6, 2006.

Philipsson J (2000): Sustainable dairy cattle breeding systems utilizing artificial insemination in less developed countries. Developing breeding strategies for lower input animal production environments. pp. 551-562. Proceedings of a workshop held at Bella, Italy, 22- 25 September 1999.

Samuel M (2005): Characterization of livestock production system: A case study of Yerer watershed, Ada'aLiben district of east Showa, Ethiopia, MSc Thesis, Alemaya University, Alemaya.

Shigdaf M, Zeleke M, Asresu Y, Mengistie T, Habetemariam A and Aynalem H (2013): Growth performance and linear body measurements of Washera, Farta and their crossbreed sheep under farmers management system in Western Highland of Amhara Region. Scientific Journal of Veterinary Advances, 9:132-143.

Sisay L (2009): Phenotypic characterization of indigenous sheep breeds in the Amhara national regional state of Ethiopia. MSc Thesis, Haramaya University, Haramaya.

Sölkner J, Nakimbigwe H and Valle-Zarate A (1998): Analysis of determinants for success and failure of village breeding programs. In: Proceedings of the 6th world congress on genetics applied to livestock production, 11-16 January 1998, Armidale, NSW, Australia. pp. 273-280.

Sölkner-Rollefson J (2003): Community-based management of animal genetic resources with special references to pastoralists. pp. 1426. In: Proceedings of the workshop on community- based management of animal genetic resources, 7-11 May 2001, Mbabane, Swaziland.

Solomon A (2014): Design of community based breeding programs for two indigenous goat breeds of Ethiopia. Doctoral Dissertation, Boku, Veinna, Austria

Solomon A and Duguma G (2000): Genetic and phenotypic parameters of growth, reproduction and survival performance of Horro sheep at Bako Agricultural Research Centre. Research Fellowship Report. Addis Ababa, Ethiopia: ILRI.

Solomon G and Tesfaye G (2009): The Awassi $\times$ Menz Sheep Crossbreeding Project in Ethiopia : Achievements, Challenges and Lessons Learned. pp.53-62. Proceedings of midterm conference of the Ethiopian Sheep and Goat Productivity Improvement Program, Achievement, Challenge and Sustainability, March 13-14, 2009, Hawassa, Ethiopia.

Solomon G, Azage T, Berhanu G and Dirk Hoekstra (2010b): Sheep and goat production and marketing systems in Ethiopia: characteristics and strategies for improvement. IPMS Working Paper 23. Nairobi, Kenya: ILRI.

Solomon G, Komen H, Hanote O, Van Arendonk JAM, Kemp S, Aynalem H, Mwai 0 and Tadelle D (2011c): Characterization and conservation of indigenous sheep genetic resources: A practical framework for developing countries.ILRI Research Report No. 27. Nairobi, Kenya, ILRI.

Solomon G, Komen H, Hanote O, Van Arendonk JAM, Kemp S, Aynalem H, Mwai O and Tadelle D (2011d): Characterization and conservation of indigenous sheep genetic resources: A practical framework for developing countries. ILRI Research Report No. 27. Nairobi, Kenya, ILRI.

Solomon G, Komen H, Hanotte $\mathrm{O}$ and Van Arendonk JAM (2008a): Indigenous sheep resources of Ethiopia: types, production systems and farmers preferences. Animal Genetic Resources Information 43:25-40.

Solomon G, Rischkowsky B, Valle-Zarate, Aynalem H, Van Arendonk JAM, Okeyo AM and Tadelle D (2014a): Breeding programs for smallholder sheep farming systems: I. Evaluation of alternative designs of breeding schemes. Journal of Animal Breeding and Genetics, 131: 341-349.

Solomon G, Tesfaye G, Zewdu E, Tadele M, Gemeda D, Markos T, Rischkowsky B, Mwai O, Tadelle D, Wurzinger M, Solkner J and Aynalem H (2013): Characterization of indigenous breeding strategies of the sheep farming communities of Ethiopia. Abasis for designing community-based breeding programs. International Center for Agricultural Research in the Dry Areas (ICARDA). 40 pp.

Solomon G, Van Arendonk JAM, Komen H, Windig JJ and Hanotte 0 (2007a): Population structure, genetic variation and morphological diversity in indigenous sheep of Ethiopia. Animal Genetics, 38:621-628.

Solomon G, Van Arendonk JAM, Komen H, Windig JJ and Hanotte 0 (2007b): Population structure, genetic variation and morphological diversity in indigenous sheep of Ethiopia. Animal Genetics 38:621-628.

Taberlet P, Pansu J and Pompanon F (2011): Conservation genetics of cattle, sheep, and goats. ComptesRendusBiologies, 334:247-254.

Tadelle M, Gemeda D, Willam A, Wurzinger M, Aynalem H, Rischkowsky B, Okeyo AM, Markos T and Sölkner J (2012): Community-based alternative breeding plans for indigenous sheep breeds in four agro-ecological zones of Ethiopia. Journal of Animal Breeding and Genetics, 129:244-253.

Tesfaye G, Ayinalem H, Markos T, Sharma AK, Sölkner J and Wurzinger M (2010): Herd Management and Breeding Practices of Sheep Owners in a Mixed Crop-Livestock and a Pastoral System of Ethiopia. African Journal of Agricultural Research,5: 685-691. 
Tesfaye G, Aynalem H, Wurzinger M, Rischkowsky B, Solomon G and Ayele A and Sölkner (2016): Review of sheep crossbreeding based on exotic sire and among indigenous breeds in the tropics: An Ethiopian perspective. African Journal of Agricultural Research, 11(11):901911.

Tsegaye T, Mengistu U, Yoseph M and Merga B (2013): Pre-Weaning Growth Performance of Crossbred Lambs (Dorper $\times$ Indigenous Sheep Breeds) under Semi- Intensive Management in Eastern Ethiopia. Tropical Animal Health and Production, 4 455-460.

Wurzinger M, Sölkner J and Iniguez L (2011): Important aspects and limitations in considering community-based breeding programs for low-input smallholder livestock systems. Small Ruminant Research, 98:170-175

Yapi-Gnoare CV (2001): The open nucleus breeding programme of the Djallonké sheep in Côte D'lvôire. In: Proceedings of the Workshop on Developing Breeding Strategies for Lower Input Animal Production Environments held 22-25 September 1999, Bella, Italy. Galal, S., Boyazoglu, J. \& Hammond, K. (Eds.). ICAR Technical Series 3. pp. 283-292.

Yenesew A (2009): Characterization of small ruminant production system and on-farm evaluation of urea treated wheat straw and concentrate feeding on sheep body weight change in Burieworeda, West Gojjam zone. MSc Thesis, Haramaya University Haramaya.

Zander KK, Drucker AG and Holm-Müller K (2009): Costing the conservation of animal genetic resources: the case of Borana cattle in Ethiopia and Kenya. Journal of Arid Environments, vol. 73 (4-5):550-556.

Zewdu E (2008): Characterization of Horro and Bonga indigenous sheep breeds of smallholders for designing community-based breeding strategies in Ethiopia. MSc Thesis, Haramaya University, Haramaya.

Zewdu E, Aynalem H, Markos T, Sharma AK, Solkner J and Wurzinger M (2012): Sheep Production Systems and Breeding Practices of Smallholders in Western and SouthWestern Ethiopia: Implications for Designing Community- Based Breeding Strategies. Livestock Research for Rural Development, 24 (7). 